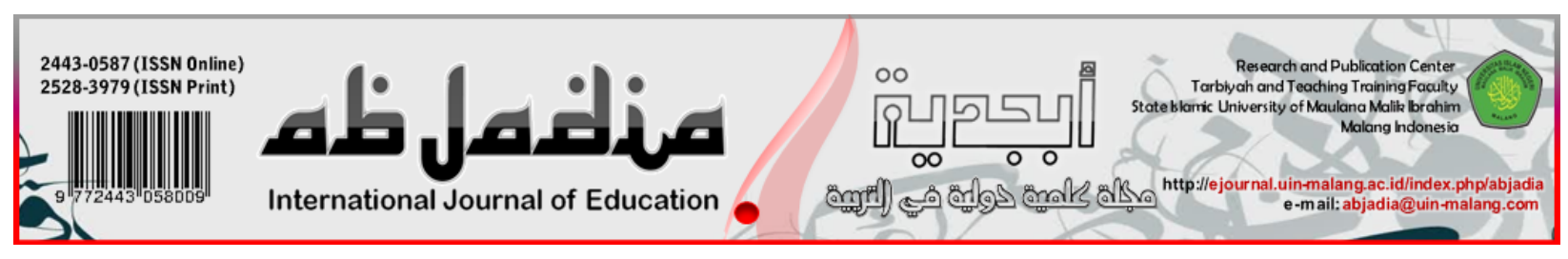

\title{
EXPLORING MATHEMATICAL CONCEPTS AND PHILOSOPHICAL VALUES IN JEMBER BATIK
}

\author{
Devita Amalia', Dwi Noviani' ${ }^{2}$, M. Fadil Djamali³, Imam Rofiki ${ }^{4}$
}

1,2,3 Mathematics Education, IKIP PGRI Jember, Indonesia

${ }_{4}^{4}$ Mathematics Education, Universitas Islam Negeri Maulana Malik Ibrahim Malang, Indonesia

Article History:

Received : 2021-08-10

Revised: 2021-08-25

Accepted: 2021-12-08

Published : 2021-12-26

\section{Keywords:}

Thinking Process, Conseptual, Mind Map, Junior High School Students

Correspondence Address:

Imam.rofiki@uin-malang.ac.id

\begin{abstract}
Ethnomathematics are different ways of doing mathematics taking into account the academic mathematical knowledge developed by different sectors of society as well as taking into account the different modes in which different cultures negotiate their mathematical practices (ways of grouping, counting, measuring, designing tools, or playing). Based on this research, this study aims to describe the results of ethnomathematics exploration in Jember batik motifs. The method of analysis used in this research is a qualitative method with an ethnographic approach. Data collection techniques are observation, documentation, and interviews. This research was conducted at Rumah Batik Rolla Jember and Rezti'z Batik Tegalsari Ambulu Jember. The research was conducted for one week. The results of this study indicate that the ethnomathematics in the Jember batik motif has a philosophical value that describes the natural wealth of Jember Regency in each of its motifs, and there are mathematical concepts in the form of geometric transformation concepts (reflection, translation, rotation, and dilation) along with the concept of number patterns
\end{abstract}

\section{(C) Introduction}

According to Koentjaraningrat (Wibawa, 2013) culture comes from the Sanskrit word buddhayah, which is the plural form of buddhi which means mind or reason. Thus culture can be defined as things that are related to reason. Culture is the whole system of ideas, actions, and the work of humans in the context of community life which is made the property of humans by learning. Culture also consists in patterned ways of thinking, feeling, and reacting, acquired and transmitted mainly by symbols, constituting the distinctive achievements of human groups, including their embodiments in artifacts: the essential core of culture consist traditional (i.e. historically derived and selected) ideas and specially their attached values (Kluckkohn, 1951). According to Koentjoroningrat (Hardian, 2018) regarding one form of culture, namely objects as human works. One example of art in the form of human work is a motif/pattern made on cloth, namely batik. Therefore batik is a form of culture.

Batik is attached to Indonesian society as a national identity and recognized as 
Indonesia national outfits (Saddhono, 2014). Lokaprasidha (2016) said that "The origin of batik dates as early as the period when our ancestor in the $17^{\text {th }}$ century attempted to write and paint of the palm frond, it predominantly with local flora and fauna, which subsenquently developed into ornaments influenced by the Hindu religion, such as clouds, temple stone relief, shadow puppet characters and other intriguing objects". According to Hermawan (Hartindya, 2019) batik is a craft that has high artistic value and has become part of Indonesian culture (especially Java). Batik Jember has a characteristic pattern that is shown by Batik Jember not only shows its beauty as a work of art but also shows certain philosophical values related to cultural identity in the Jember Regency. Some choices of batik patterns that are very popular in Jember are batik with tobacco leaf motifs. According to Cahbagoes (Hartindya, 2019), Jember Regency is so well-known as one of the tobacco producers in Indonesia, it is not surprising that local people have creative ideas by immortalizing them on a piece of written batik cloth which we will call Jember batik.

According to Surya (Windria, 2016), Indonesian batik was officially recognized by UNESCO as an intangible cultural heritage in 2009. This indicates that Indonesian batik has characteristics that do not exist in other countries. More specifically, Batik in Indonesia is considered to have a wealth of symbols and philosophies of life for the Indonesian people. However, Batik is not only rich in national culture and philosophy, without realizing it, batik is also rich in mathematical concepts. Mathematics Education have through the most critical periods in its long history, a history recorded since western classical antiquity. The prominent role of mathematics in Greek civilisation placed mathematics in a unique position in the roots of modern science and technology, and in the development of the universal model of an industrial society (D'Ambrosio, 1986).

Ethnomathematics is a cultural practice that allows mathematical concepts to be embedded and recognizes that all people develop special ways of carrying out mathematical activities (Fajriyah, 2018). The terms ethno describes "all of the ingredients that make up the cultural identity of a group which include language, codes, values, jargon, beliefs, food, dress, habbits, and pfysical traits" (Arismendi-Pardi in Utete, 2017). According to D'Ambrosio (Arwanto 2017) that the purpose of ethnomathematics is to recognize that there are different ways of doing mathematics by considering academic mathematical knowledge developed by various sectors of society and by considering the different modes in which different cultures negotiate their mathematical practices. (how to group, count, measure, design buildings or tools, play, and more). Ethno-mathematics and Ethno-science present a realistic history of mathematics and science pointing to a variety of examples used to solve problems emerging in the every-day lives of various cultures. In addition, there is recognition that the learning of mathematics (Utete, 2017). Science also is a unique process for each individual learner because of their individual living conditions, upbringing, background, and chores with a variety of skills and interests acquired from home education. 
Concepts in mathematics are arranged hierarchically, structurally, logically, and systematically starting from simple concepts to complex concepts. Mathematics learning is like a continuous link and makes the chain intact. Concepts in mathematics are interrelated, even simple concepts have a role as a prerequisite for understanding more complex concepts. (Matitaputy, 2018).According to James and James (Education et al., N.d.) Mathematics is the science of logic, regarding forms, arrangements, quantities, and concepts that are related to one another. Mathematics is divided into three major parts, namely algebra, analysis, and geometry. The application of mathematics itself is often encountered in everyday life, for example throughout Indonesia, one of which is batik. In making batik, the previous batik maker must have designed a motif that will be drawn on the cloth.

Ethnomatematics in this research on batik Jemberis carried out by exploring mathematical concepts and philosophical values contained therein.Philosophical values are values based on philosophy (Kamila, 2016). Meanwhile, philosophy according to Nasution (Kamila, 2016) thinks according to order (logic) freely (not tied to tradition, dogma, and religion) and profusely, so that it gets to the basics of the problem. From the statements of experts, it can be concluded that the value of philosophy is a value based on a systematic and comprehensive point of view to investigate something to obtain its truth.

Several studies about ethnomathematics have been carried out on several types of batik in different locations in Indonesia. such as the research conducted by Arwanto (2017) on the typical Cirebon Trusmi batik, which shows that in Cirebon Cirebon batik contains mathematical elements, including geometric concepts of symmetry, transformation (reflection, translation, and rotation), and congruence.While Lestari, et al (2018) in their research results show thatethnomathematics in Batik Bali is more to geometrical concept in line of strong Balinese culture element.Tresnadi, et al (2015) findings suggest that the values found in Indonesian batik ornaments in the Nitiki game clearly show thepatterns of how traditional culture of batik survives and thrives in Indonesian society, as well asshow the flexibility of batik against the current development of modern culture, including itsintegration as culture-based content in interactive media.Therefore, the researcher wants to show how the results of ethnomathematics exploration in Jember batik and what mathematical concepts are contained in the batik motifs that are made and reveal the philosophical value contained therein. Based on the description above, the authors is interested in researching with the title "Exploration of Jember Batik Ethnomatics to Reveal Philosophical Values and Mathematical Concepts".

\section{[Q] Method}

This type of research is qualitative research with an ethnographic approach. According to Bogdan and Taylor (Ufie et al., 2014), defining qualitative research methods as research procedures that produce descriptive data in the form of written or spoken 
words from people and observed behavior. While the ethnographic approach is an activity to collect information or data that is carried out systematically about the way of life as well as various social activities and various cultural objects of the society.This study uses an ethnographic approach to reveal philosophical values and to analyze mathematical concepts in Jember's typical batik motifs.

The data analysis technique is carried out by the following steps: Data reduction is the process of selecting which data is relevant to the research objectives so that from this the researcher will select data from observations, interviews, and documentation. The researcher sorted out the batik motifs that have philosophical values and also have a mathematical concept from each of the Jember batik production houses. After knowing what data is needed, it is followed by the data presentation stage. The presentation of data in this study uses descriptive data presentation obtained from data reduction. For the last stage, the data analysis technique in this study is drawing conclusions. Researchers can draw conclusions from the results of presenting the data according to the research problem formulation.

In this study, the researcher acts as a research instrument (human instrument), therefore in this case the researcher acts as a data collector and his role cannot be replaced. The subjects in this study were various kinds of batik motifs obtained from 2 batik craftsmen, namely the Rolla Batik House on Jalan Mawar No. 75 and Rezti's Batik Tegalsari in Desa Ambulu Jember. Data collection procedures in this study using observation (non-participant), interviews, and documentation. The research location used as a place of research is the Rolla Batik House on Jalan Mawar No. 75 Jember and Rezti's Batik Tegalsari in Desa Ambulu Jember. The length of the study in this study was approximately one week. Checking the validity of the data used in this study using the triangulation of sources.

\section{Result}

The results of the research are a description of the names and types of Jember batik in the form of various types of motifs that contain philosophical values and mathematical concepts. When examined carefully, the Jember batik motif will find philosophical values and some mathematical concepts in it. The philosophical values contained in the Jember batik motif include:

\section{Tobacco Batik Motif}

Of the two batik production houses in Jember, namely Rumah Batik Rolla Jember and Rezti's Batik Tegalsari Ambulu Jember, in general, they have similarities in making batik motifs. In both places, there are Jember's iconic batik motifs, one of which is the Tobacco Batik Motif. 


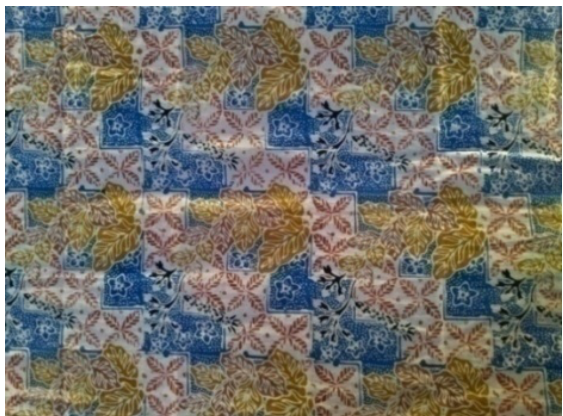

Figure 1. Mathematical batik motifs

Mathematical Batik Motif has mathematical meaning because it contains mathematical elements, namely squares. Inside the square is a tobacco motif that is crossed so that each side is the same. So the form of mathematical motives is not just making it like a cube. However, the cube motif is combined with other batik motifs.

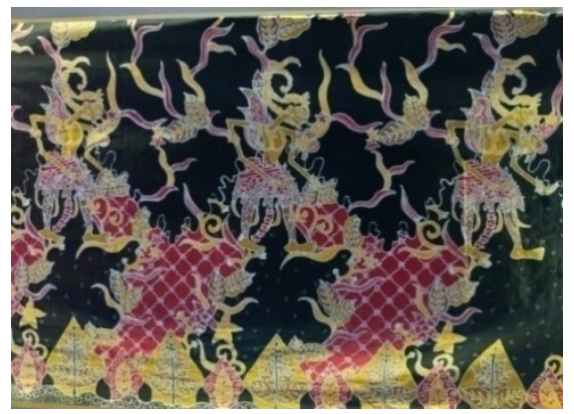

Figure 2. Jember puppet batik motif

The Jember puppet batik motif shows the culture because there are wayang motifs. So in this motif, there is a tobacco motif and there is a curtain/puppet screen. Then there is the puppet motif, which actually comes from the Jogja area. The standard is Jogja wayang using lurik and truntum. Lurik is a cloth with a small striped motif which has traditionally been the typical clothing of rural men among Javanese ethnic groups, while trumtum, is a typical Jogja batik motif created by Kanjeng Ratu Kencana (Permaisuri Sunan Paku Buwana III). Because this puppet is placed in the Jember batik motif so that it is combined and matched using tobacco.

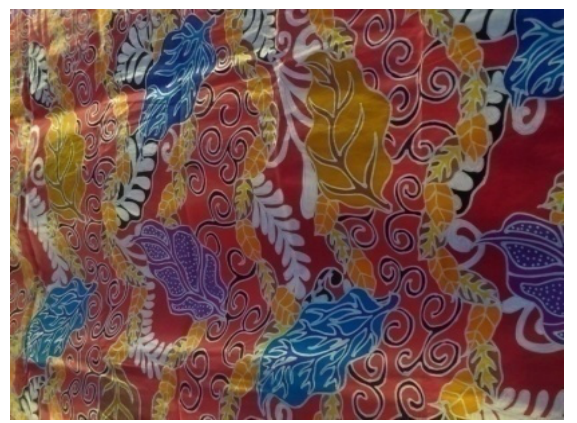

Figure 3. Tobacco motifs and types,

The tobacco batik motif with its art shows the diversity of types of tobacco. So the characteristics of this type of tobacco are smaller musk tobacco, and large Na Oogst 
tobacco. In this batik, the tobacco motif is made with the art, not only in the form of a single tree.

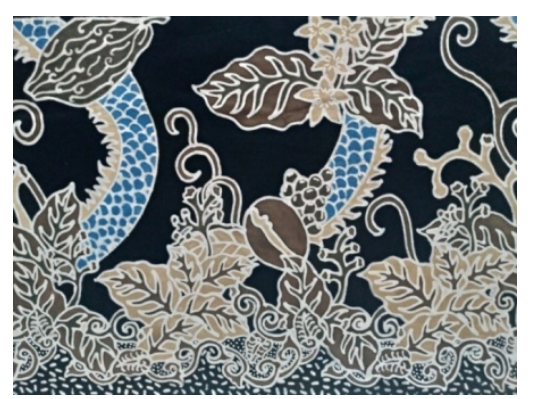

Figure 4. Tobacco coffee batik motif

In the tobacco batik motif which means prosperity. The tobacco coffee motif means the prosperity of the country, because coffee and tobacco typical of Jember itself, when exported, have high prices so that they become excellent in the eyes of the world.

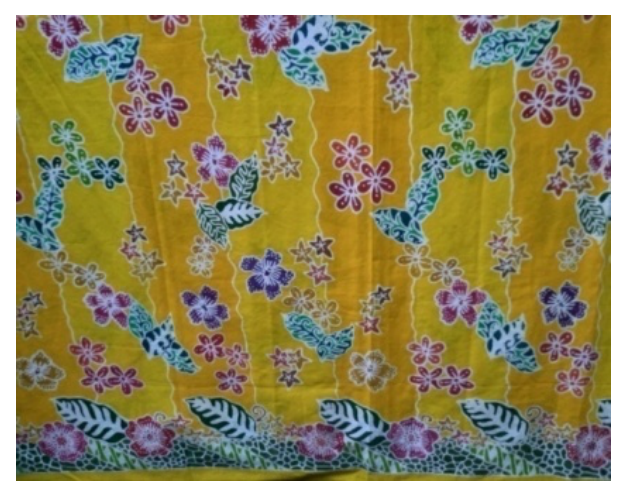

Figure 5. Tobacco batik motifs

In tobacco batik motifs, mix and match with chrysanthemums, jasmine flowers, and other types of flowers. Because there are not too many motifs, so the colors are made in various ways that aim to follow fashion.

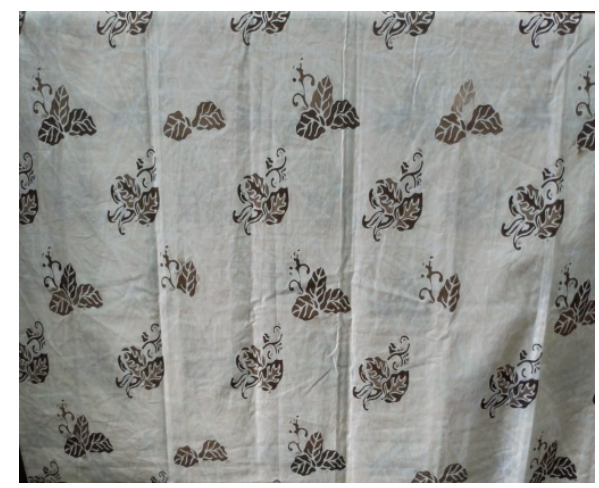

Figure 6. Usual tobacco batik motif

In simple tobacco, motifs have meaning, namely natural colors which are characteristic of Indonesian colors. Batik makers want to highlight the characteristic color of Indonesia, namely natural colors. The natural color itself is the simplest and most unhappy color of brown. Because according to the color batik from Indonesia, it is more 
natural and environmentally friendly.

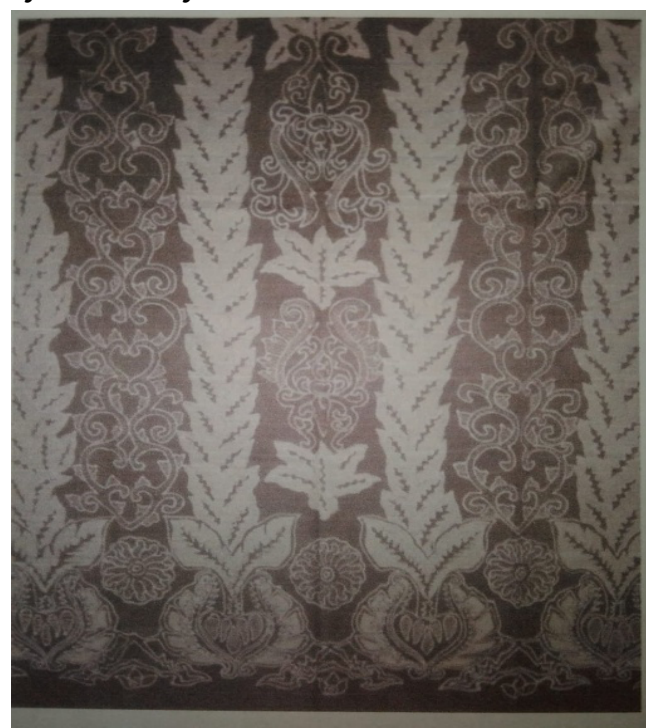

Figure 7. The batik motif of Na Oogst Serenteng

The batik motif Na Oogst Serenteng means Na Oogst which is the leading type of tobacco in Jember Regency which is commonly used as a binding wrapper and to fill the aroma of high-quality cigars, renting which means a series. So that this batik motif has a philosophical value to become a quality human being, of course, it must be able to go through a series of continuous learning processes, depicted with $\mathrm{Na}$ Oogst tobacco which is strung together.

\section{Coffee Batik Motif}

Besides Batik Batik Motif, Jember also has other typical Jember batik motifs, namely coffee. Similar to the Tobacco batik motif, the Kopi batik motif is also produced in the two Jember Batik Production Houses, namely Rolla Jember Batik House and Rezti's Batik Tegalsari Ambulu Jember.

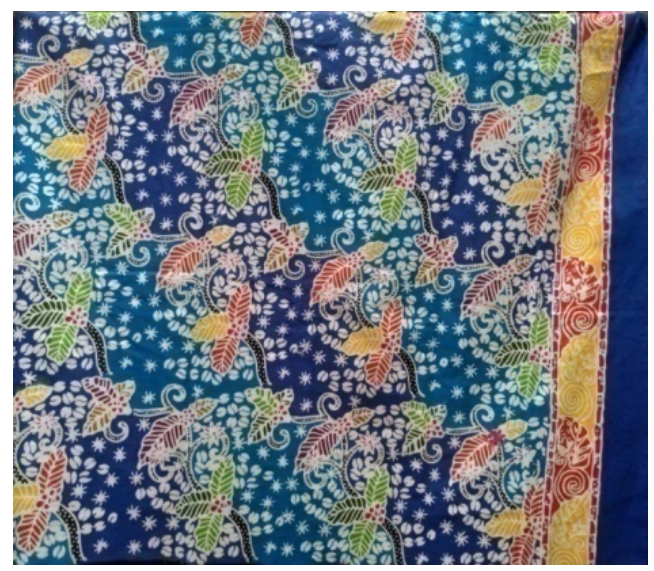

Figure 8. Coffee batik motifs

In the coffee batik motif, the meaning of the coffee motif is made in multi-colors. Which aims to make the motif look bright. The color used in this batik motif is a color that was adopted from Japan. 


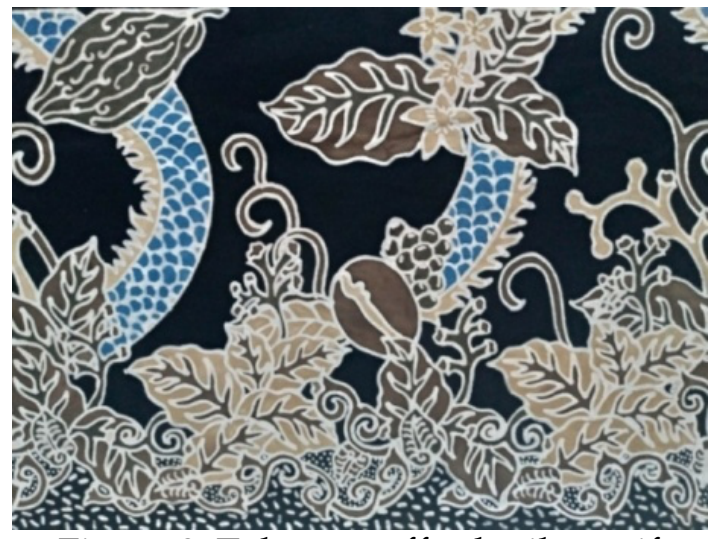

Figure 9. Tobacco coffee batik motif

In the tobacco batik motif which means prosperity. The tobacco coffee motif means the prosperity of the country, because Jember coffee itself, when exported, has a high price so that it becomes excellent in the eyes of the world.

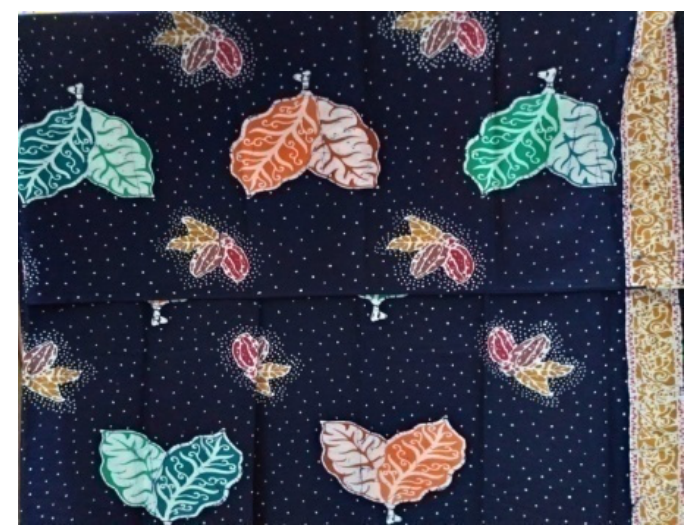

Figure 10. Coffee and cocoa batik motifs

It shows that tobacco and cocoa are the superior products of the Jember Regency that are taken into account.

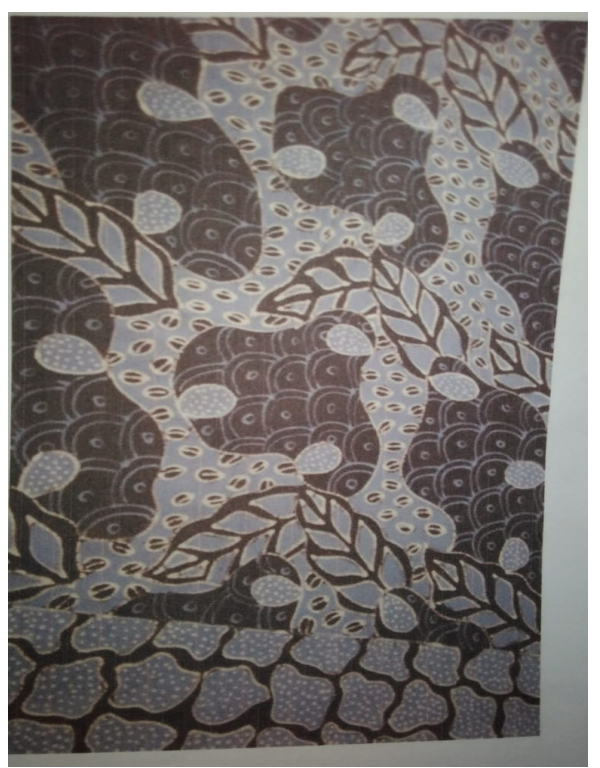

Figure 11. Watu ulo coffee batik motif 
In the batik motif, Kopi Watu Ulo means Coffee is a drink that is identified with a bitter taste and Watu Ulo is depicted as a longitudinal stone resembling snake scales. So that the philosophical value of this motif illustrates the geographical location of South Jember which has rocks resembling snake scales (Watu Ulo beach). As well as there are lesehan stalls providing coffee along the road as a place to relax.

From the explanation above, it is evident that the Jember batik motif has philosophical values. The Jember batik motif not only has philosophical values but there are mathematical concepts contained in the Jember batik motif, including the concept of geometric transformation (translation, reflection, dilation, and rotation) and the concept of number patterns. Jember batik motif can be a tool to introduce mathematical concepts so that it can facilitate understanding of mathematical concepts such as the concept of geometric transformation and the concept of number patterns. The study of the mathematical concepts contained in the Jember batik motif is as follows:

\section{The concept of transformation in the Jember batik motif}

The Jember batik motif contains the concept of geometric transformation, such as reflection, translation, and rotation. The study of these concepts on batik motifs is described as follows.

\section{Concept of Reflection on Jember Batik Motif}

The making of batik motifs in Figure A.1 and Figure A.2 contains the concept of reflection, this is evidenced by the location of the motif

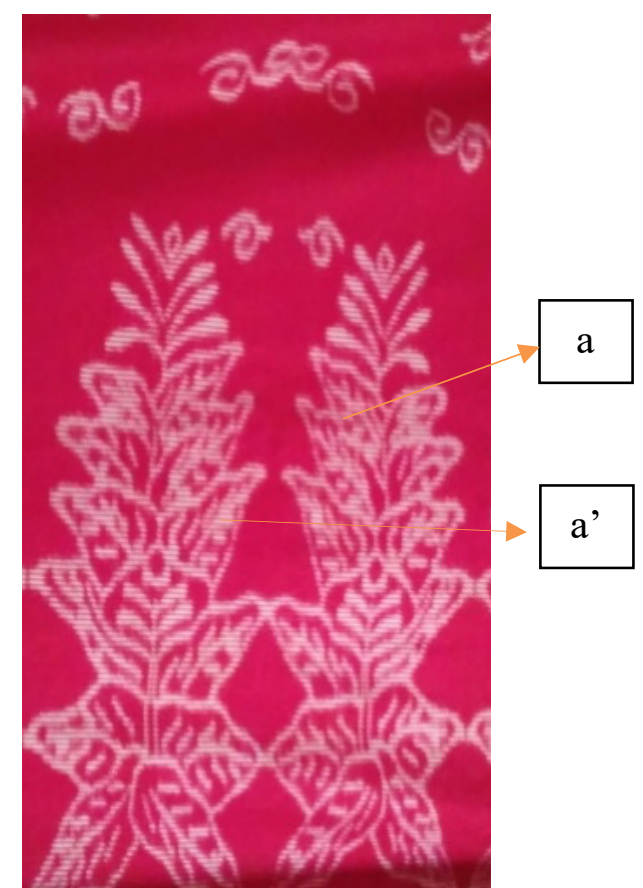

Figure 12a. Reflection on the Motive (Batik Rolla Jember) 


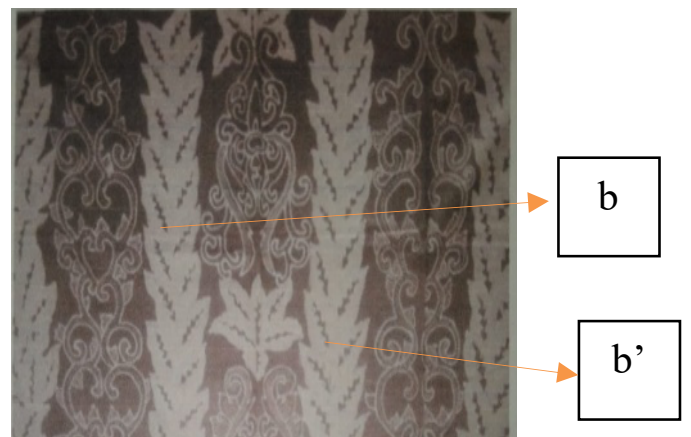

Figure 12b. Reflection on Motives

(Rezti'z batik Tegalsari Ambulu)

In Figure 12a batik motif an if it is reflected into a batik motif a '. Such is the case with Figure $12 b$ on batik motif $b$ if it is reflected into batik motif $b$ '. So it can be said that the Jember batik motif has the concept of reflection (reflection).

\section{The Concept of Translation in Jember Batik Motif}

Another mathematical concept contained in the making of Jember batik is the concept of translation. Shifting the batik motif from one position to another clearly shows that the concept of translation is involved in making batik motifs. For example, Figure 13a. and Figure 13b. In Figure 13b. it is shown with motive an if it is shifted to motif a 'then it is shifted to motif a' 'as well as in Figure 13b. it is shown with motif $b$ if it is shifted to the right to become motif $b^{\prime}$ then it is shifted right to motif $b^{\prime}$, and so on.
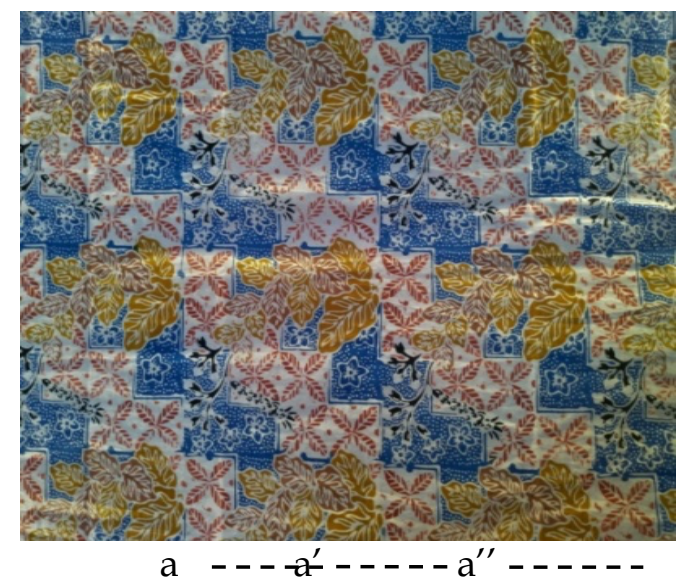

Figure 13a. Translation on Motives

(Batik Rolla Jember) 


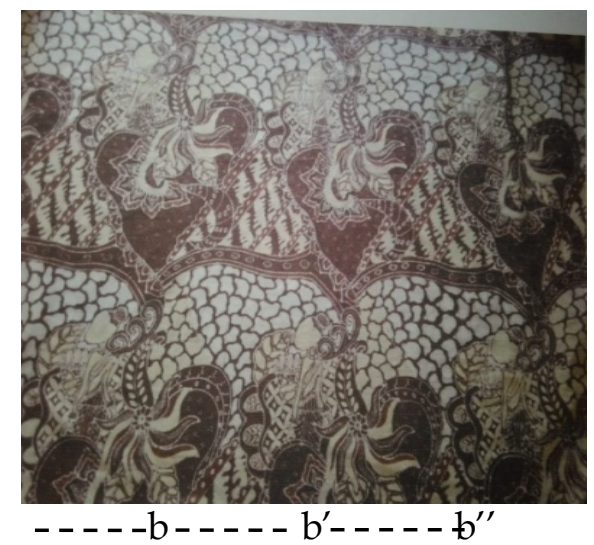

Figure 13b. Translation on the Motive (Rezti'z batik TegalsariAmbulu)

\section{The Concept of Rotation in Jember Batik Motif}

In making Jember batik motifs there is also a rotation concept. The concept of rotation is obtained by rotating the motif made according to the axis. An example of the rotation concept is shown in Figure 14a. and Figure 14b.. in Figure 14a. the motif is mirrored horizontally, not much different in Figure 14b. the batik motif is reflected horizontally.

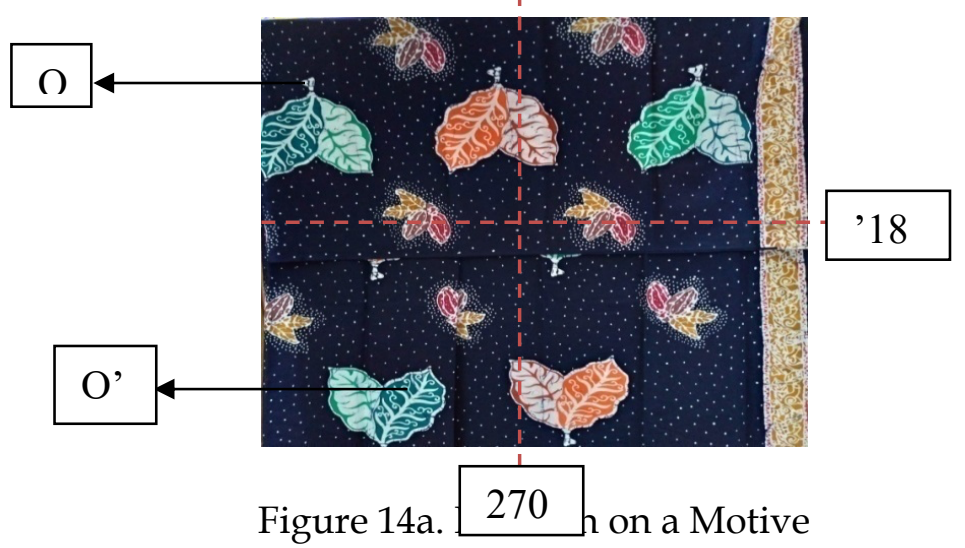

(Batik Rolla Jember)

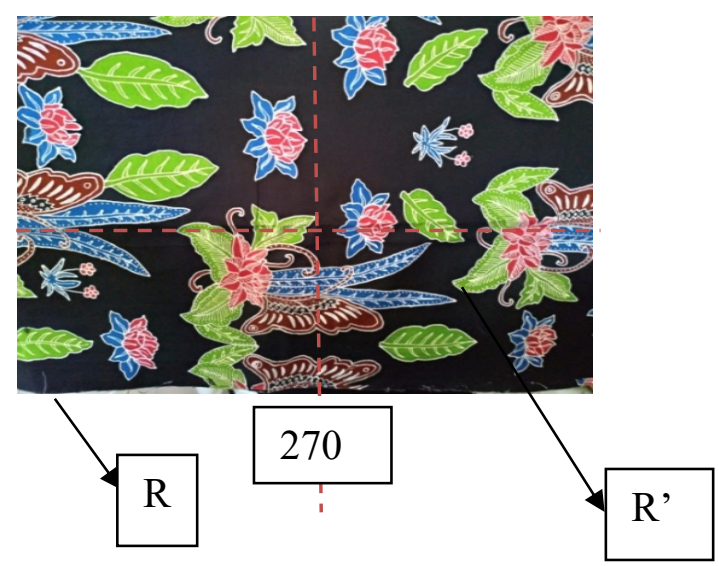

Figure 14b. Rotations on a Motive

(Rezti'z batik Tegalsari Ambulu) 
In Figure 14a., the batik motif $\mathrm{O}$ 'is rotated $180^{\circ}$ it becomes the $\mathrm{O}^{\prime}$ batik motif. In such a way, Figure $14 \mathrm{~b}$. with a motive $R$ if it is rotated at $45^{\circ}$ it becomes batik motif R '. So it can be concluded that the Jember batik motif has the concept of rotation.

\section{The Concept of Dilatation in Jember Batik Motif}

In making Jember batik motifs there is a concept of dilation. The concept of dilation is meant to duplicate the batik motif but in different sizes. Then put together a Jemebr batik motif so that it looks more beautiful. Examples of Jember batik motifs that have a dilation concept are shown in Figure 15a. and Figure 15b.

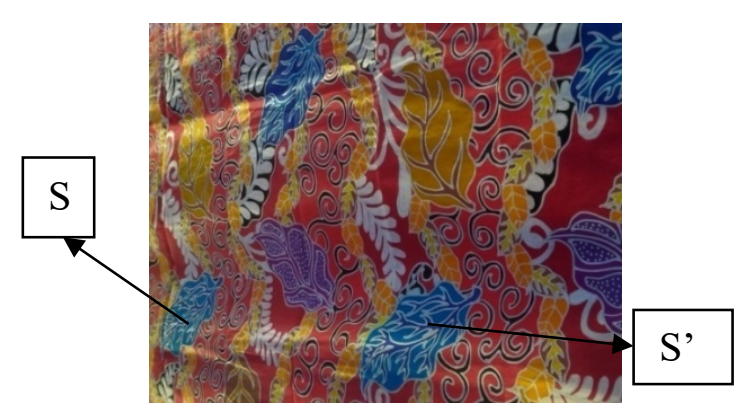

Figure 15a.Dilation on Motif (Batik Rolla Jember)

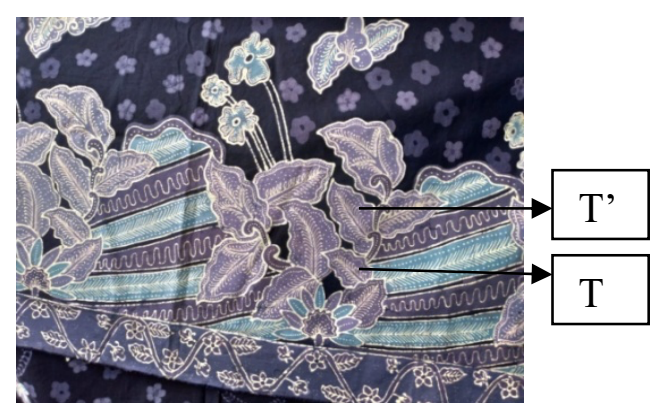

Figure 15b. Dilation on Motif

(Rezti'z batik TegalsariAmbulu)

In Figure 15a., the $S$ batik motif becomes a batik $S$ 'motif. The same is the case in Figure 15b. the T batik motif when it is dilated it becomes the $\mathrm{T}$ 'batik motif. So it can be concluded that the Jember batik motif has the concept of Dilatation

\section{The Concept of Number Patterns in the Jember Batik Motif.}

In the making of Jember batik motifs, there is also the application of the concept of numbers. This is shown in Figure 16a. and Figure 16b. In Figure 16a. there are different kinds of motifs with regular patterns, namely 1-1 patterns as well as in Figure 16b. there are 2 batik motifs with regular patterns, namely 1-1.

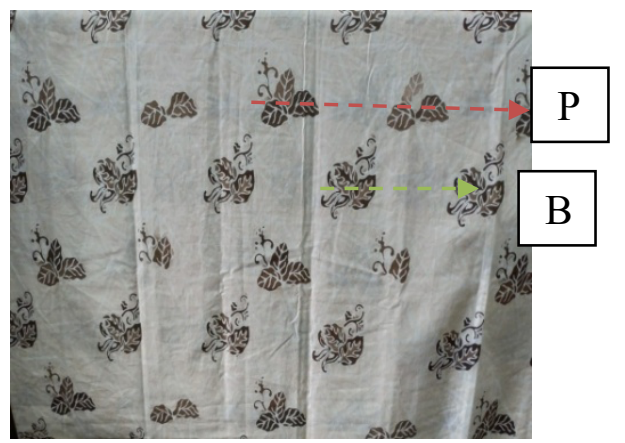

Figure 16a. Number Pattern on Motif

(Batik Rolla Jember) 


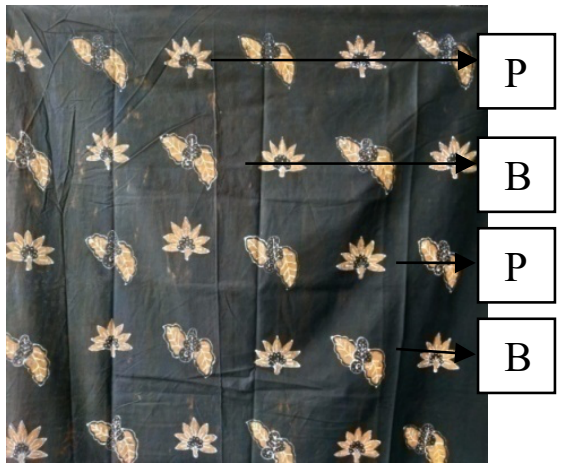

Figure 16b. Pattern of Numbers on Motifs

(Rezti'z batik Tegalsari Ambulu)

In Figure 16a., the batik motif of the batik motif $\mathrm{p}$ is 1 with the batik $\mathrm{B}$ motif so that it can be said that the batik has a 1-1 pattern. Likewise in Figure 16b, the batik motif P is patterned 1-1 after the batik motif B. So it can be concluded that the Jember batik motif contains the concept of a number pattern. In my research, there are several philosophical values in Jember batik motifs. At the Rolla Jember batik house, most of the philosophical values contained in the Jember batik motif are tobacco leaves, coffee, and cocoa. Not much different in Rezti'z batik Tegalsari Ambulu Jember, the Jember batik motif produced has a philosophical value, namely the batik motifs of tobacco leaves, coffee, and cocoa. The Jember batik motif shows a mathematical concept. Mathematical concepts are concepts in mathematics that are arranged hierarchically, structured, logically, and systematically starting from simple concepts to complex concepts.

Research on batik ethnomathematics exploration in Jember to reveal philosophical values and mathematical concepts can be linked to research on batik ethnomathematics. In research conducted by Hartindya (2018) producing material products in the form of student worksheets in his research, it was shown that Jember batik contained a mathematical concept, namely the concept of transformation geometry (reflection, rotation, dilation, and translation) which was different from the results of this study. This research shows that the Jember batik motif contains a mathematical concept, namely not only the concept of geometric transformation but also the concept of number patterns. Furthermore, research conducted by Zayyadi (2017) results of his research in the form of mathematical concepts contained in Madura batik motifs, namely: straight lines, curved lines, parallel lines, symmetry, points, angles, rectangles, triangles, circles, lines, and similarity concepts. . Based on the relationship between the two studies, it will be used as a guide in exploring ethnomathematics in Jember batik motifs. This research focuses on the process of uncovering the philosophical values and mathematical concepts contained in the Jember batik motif.

Research on Jember batik motifs has also been conducted by (Wulandari et al., 2017) regarding the development of labako batik designs by combining dragon curve fractal geometry and tobacco leaf patterns. This research focuses on dragon curve fractal geometry. In addition, research on Jember batik conducted by (Sumardi et al., 2018) 
regarding the analysis of the study and recognition of Jember batik motifs through the Jember Fashion Carnival focused on the development of the local tradition of batik as a natural asset of internationalization through the Jember Fashion Carnaval (JFC) event.

\section{筍 Conclusion}

Based on the results and discussion above, it can be concluded that Jember batik has a philosophical value in each of its motives. Jember batik motif itself raises a lot about the natural wealth owned. In addition, the Jember batik motif contains mathematical elements, including the concepts of transformation geometry (reflection, translation, rotation, and dilation) and the concept of number patterns.

\section{Suggestion}

Based on the results of the research, some suggestions that the researcher can convey, namely Ethnomatematics in the Jember batik motif, can be used in the learning process in the classroom, especially by introducing one of the typical cultures of Jember, namely batik typical of Jember so that students will be more interested in learning mathematics through their local culture. It is hoped that there will be further research that discusses the development of a learning model through regional culture or about the application of a regional culture-based learning process.

Each Jember batik motif contains certain philosophical values according to the natural wealth of the Jember Regency. Jember batik motifs also contain mathematical concepts in the manufacturing process. The mathematical concepts involved in making motifs include the concept of transformation (reflection, translation, rotation, and dilation) and the concept of number patterns. This is indicated by each motif produced by the Jember batik production house.

\section{Bibliography}

Arwanto. (2017). Eksplorasi Etnomatematika Batik Trusmi Cirebon untuk Mengungkap Nilai Filosofi dan Konsep Matematis.Phenomenon: Jurnal Pendidikan MIPA, 2017.

D’Ambrosio U. (1986) Socio-Cultural Bases for Mathematical Education. In: Carss M. (eds) Proceedings of the Fifth International Congress on Mathematical Education. Birkhäuser, Boston, MA. https://doi.org/10.1007/978-1-4757-4238-1_1.

Fajriyah, E. (2018). Peran etnomatematika terkait konsep matematika dalam mendukung literasi. PRISMA: Prosiding Seminar Nasional Matematika, 1, 114-119. https://journal.unnes.ac.id/sju/index.php/prisma/ 
Hardian, C. D. (2018). Etnomatematika, Analisis Pola Dan Motif Batik Berdasarkan Wallpaper Group Serta Analisis Aktivitas Fundamental Matematis Menurut Bishop Pada Industri Batik Di Desa Wijirejo, Kecamatan Pandak, Kabupaten Bantul, Daerah Istimewa Yogyakarta. 1-136.

Hartindya, R. P. (2019). Digital Digital Repository Repository Universitas Universitas Jember Jember Digital Digital Repository Repository Universitas Universitas Jember.

Kamila, N. Z. (2016). Fakultas bahasa dan seni universitas negeri semarang 2015. Unnes, 145-146.

Kluckhohn C. (1951). The Study of Culture. in Lerner and H. D. Lasswell (eds). The Policy Sciences, p. 86-101. Standford, CA: Stanford University Press.

Lestari, Mei., et al. (2018). Ethnomathematics Elements in Batik Bali Using Backpropagation Method. Journal of Physics: Conf. Series 1022 (2018) 012012. http: 10.1088/1742-6596/1022/1/012012.

Lokaprasidha, Pramesi. (2019). The History of Batik and The Development of Kampung Batik Kauman as a Local to International Tourism Destination.Journal of Tourism and Creativity, Vol.1, No.1, 2019, ISSN. 2549-483X, E-ISSN. 2716-5159.

M.Pd, A. A. (2017). Eksplorasi Etnomatematika Batik Trusmi Cirebon Untuk Mengungkap Nilai Filosofi Dan Konsep Matematis. Phenomenon : Jurnal Pendidikan MIPA, 7(1), 40. https:/ / doi.org/10.21580/phen.2017.7.1.1493

Matitaputy, C. (2018). Miskonsepsi Siswa dalam Memahami Konsep Nilai Tempat Bilangan Dua Angka. Mosharafa: Jurnal Pendidikan Matematika, 5(2), 113-119. https:/ / doi.org/10.31980/mosharafa.v5i2.266

Pendidikan, P., Jurusan, M., Stain, T., Abstrak, P., Sekolah, B., Pertama, S. M., Umum, S. M., Dasar, S., Pertama, S. M., Umum, S. M., Sekolah, M., Sekolah, M., \& Kunci, K. (n.d.). Hakikat Pendidikan Matematika Oleh: Nur Rahmah. 1-10.

Saddhono, K.., Sahid, TW., Muhammad, TA., Masakatsu, Tozu. (2014). The Study of Philosophical Meaning of Batik and Kimono Motifs to Foster Collaborative Creative Industry. Asian Social Science, Vol. 10, No. 9; 2014, ISSN. 1911-2017, E-ISSN. 1911-2025.

Sumardi, S., Kantun, S., Ayu, A., \& Mashudi, M. (2018). Batik Social and Cultural Legitimacy Globalization: Study Analysis and Recognition Batik Motif Jember through Jember Fashion Carnival. 125(Icigr 2017), 53-57. https:// doi.org/10.2991/icigr17.2018.13

Tresnadi, Chandra and Agus, Sachari. (2015). Identification of Values of Ornaments in Indonesian Batik in Visual Content of Nitiki Game. Journal of Arts E Humanities, Vol. 4, No. 08, Pp: 25-39.

Ufie, A., Kualitatif, P., Nugrahani, F., Parupalli, S. R., Nteli, A., Zafiri, M., Kolokytha, E., 
Loutrouki, S., Valsamidis, S., Florou, G., Nursalam, 2016, metode penelitian,

Okada, Y., Sawaumi, T., Ito, T., Erasmus, N., Overwater, I. E., Parupalli, S. R., Miskam,

N. N., Saidalvi, A., ... Saebani. (2014). dalam Penelitian Pendidikan Bahasa. 信阳师

范学院, 1(1), 32. https:/ / doi.org/10.1016/j.sbspro.2015.04.758

Utete, Christina., et al. (2017). Exploring How Modern Sciences Impede The

Development of Indigenous Knowledge (IK) [Ethno-Science and EthnoMathematics] in The Kavango East Region: A Case Study. Journal for Studies in Humanities and Social-Sciences, Vol. 6, No. 2, pp. 68-88, 2017-ISSN.2026-7215.

Wibawa, S. (2013). Nilai filosofi jawa dalam. Litera, 12(2), 328-344.

Windria, H. (2016). BATIK KAYA MATEMATIKA Memanfaatkan Motif Batik dalam Kelas Matematika. Prosiding Seminar Nasional Pendidikan Matematika 2016, 1, 279 291.

Wulandari, E. Y., Purnomo, K. D., \& Kamsyakawuni, A. (2017). Development Design Labako Batik with Combine Fractal Geometry Dragon Curve and Tobacco Leaf Motif. Jurnal ILMU DASAR, 18(2), 125. https:/ / doi.org/10.19184/jid.v18i2.5650

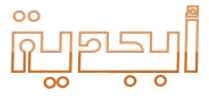

